\title{
The Antioxidant and Hypoglycemic Properties and Phytochemical Profile of Clusia latipes Extracts
}

\author{
Ronald Silva-Rivas ${ }^{1}$, Natalia Bailon-Moscoso ${ }^{2}$, Luis Cartuche ${ }^{1}$, Juan Carlos Romero-Benavides ${ }^{1, *}$
}

Ronald Silva-Rivas' ${ }^{1}$, Natalia

Bailon-Moscoso' ${ }^{2}$, Luis Cartuche', Juan Carlos Romero-Benavides ${ }^{1, *}$

'Departamento de Química y Ciencias Exactas, Sección de Química Básica y Aplicada, Universidad Técnica Particular de Loja, Loja, ECUADOR.

${ }^{2}$ Departamento de Ciencias de la Salud, Sección de Genética Humana, Microbiología y Bioquímica Clínica, Universidad Técnica Particular de Loja, Loja, ECUADOR.

\section{Correspondence}

\section{Juan Carlos Romero-Benavides}

Departamento de Química y Ciencias

Exactas, Universidad Tecnica Particular de Loja (UTPL), San Cayetano alto s/n, Loja, CP:1101608, ECUADOR.

E-mail: jcromerob@utpl.edu.ec History

- Submission Date: 01-10-2019;

- Review completed: 06-11-2019;

- Accepted Date: 11-11-2019.

DOI : 10.5530/pj.2020.12.21

Article Available online

http://www.phcogj.com/v12/i1

\section{Copyright}

(C) 2020 Phcogi.Com. This is an openaccess article distributed under the terms of the Creative Commons Attribution 4.0 International license.

\begin{abstract}
Introduction: The prevalence of diabetes has increased more rapidly in low and middleincome countries than in high-income countries. Type 2 diabetes mellitus (DM2), which is the most common form of diabetes, is caused by the inefficient use of insulin in the body and is characterized by disrupted insulin action or secretion. Also, oxidative stress plays an important role in the development of disease. The goal of this study is to identify the antioxidant and hypoglycemic properties of Clusia latipes, an endemic species of Central and South America. Methods: The antioxidant and hypoglycemic capacity of the extracts (hexane, ethyl acetate, and methanol) of the leaves and stems of Clusia latipes were evaluated. From the most potent extract, the phytochemical study was carried out and fractionated. Antioxidant activity was measured using 2,2-diphenyl-1-picrylhydrazyl (DPPH) and 2,2-azinobis (3-ethylbenzothiazoline6-sulfonic acid) diammonium salt (ABTS), while hypoglycemic capacity was measured by alpha-glucosidase inhibition. Results: The extracts with the highest antioxidant capacity are the extracts with the highest $\alpha$-glucosidase inhibition activity. Inhibitory activity increased in samples extracted with medium polar (ethyl acetate) and polar (methanol) solvents. Phytochemical screening of these extracts revealed the presence of alkaloids, carbohydrates, flavonoids/xanthones, quinones, saponins, and tannins. The highest $\alpha$-glucosidase inhibitory activity was detected in the ethyl acetate fraction obtained from leaf methanol extract, with a half-maximal inhibitory concentration $\left(\mathrm{IC}_{50}\right)$ value of $0.90 \mu \mathrm{g} / \mathrm{ml}$. The major constituent isolated from the same fraction was isoquercitrin.

Key words: $\alpha$-glucosidase inhibitory activity, DPPH, Phytochemical screening, Type 2 diabetes mellitus
\end{abstract}

\section{INTRODUCTION}

Diabetes mellitus has become one of the primary threats to human health, with its rapidly increasing prevalence, and gravely debilitating clinical complications ${ }^{1}$. Over the past decade, diabetes prevalence has risen faster in low and middle-income countries than in high-income countries. The World Health Organization (WHO) has projected that DM will be the 7th leading cause of death in 2030. Diabetes is a chronic disease that occurs when the pancreas does not produce sufficient insulin or when the body cannot effectively use the insulin it produces. Insulin is a hormone that regulates blood sugar. Hyperglycemia or high blood sugar is a common effect of uncontrolled diabetes, which might lead to serious heart, blood vessel, eye, kidney, and nerve damage over time ${ }^{2,3}$. Type 2 diabetes mellitus (T2DM), which is the most common form of diabetes, is produced by the ineffective use of insulin in the body and is characterized by disorders of insulin action and secretion. Either one of these mechanisms could be the predominant feature, but generally, when diagnosed, both are manifested ${ }^{1}$. In T2DM, particularly, it is believed that oxidative stress caused by overproduction of reactive oxygen species (ROS) is the cause of vascular complication development ${ }^{4}$. Hyperglycemic condition of DM patients will produce tissue damage via the formation of ROS through five major mechanisms that have been shown to be activated by mitochondrial ROS overproduction: increased flux of glucose and other sugars through the polyol pathway; increased formation of advanced glycation end products; increased expression of the receptor for advanced glycation endproducts (RAGE) and its activating ligands; activation of protein kinase $\mathrm{C}$ isoforms; and over-activity of the hexosamine pathway $^{5-7}$.

Alpha-glucosidase is a critical enzyme that catalyzes the cleavage of absorbable monosaccharides starting with disaccharides and oligosaccharides ${ }^{8}$. In this manner, a-glucosidase inhibitors reduce postprandial hyperglycemia by slowing intestinal carbohydrate digestion ${ }^{9}$. Alpha-glucosidase inhibitors are capable of suppressing postprandial hyperglycemia; they are generally used to prevent or treat type II diabetes ${ }^{10}$.

Plants play an important role in health care and are an important source of potentially bioactive substances ${ }^{11}$. The genus Clusia is widely distributed in the tropical and subtropical regions of Central and South America ${ }^{12}$. In the species of this genus, a great variety of biological activities have been found: broad-spectrum antimicrobial activity; chemopreventive cancer effects and antioxidant activity $^{13}$; anti-inflammatory and anti-hepatotoxic activity and inhibitory action of the human immunodeficiency virus (HIV) $)^{14-16}$; and cytotoxic 
activity $^{17,18}$. In the present study, both the antioxidant and anti-glycemic activity of leaf and stem extracts of $C$. latipes were evaluated.

\section{MATERIALS AND METHODS}

\section{Plant material}

The leaves and stems of Clusia latipes Planch. \& Triana, Clusiaceae were collected in Gonzanama-Quilanga in the Loja province of Ecuador, and species identification was made by Fani Tinitana, $\mathrm{PhD}$. A voucher specimen (PPN-CI 002) was deposited at the Herbarium of the Universidad Técnica Particular de Loja, Ecuador.

\section{Extraction and partitions of Clusia latipes}

For 7 days at $30^{\circ} \mathrm{C}$, the plant material was dried in a tray dryer with airflow and then manually pulverized. Leaves and stems were processed separately. The pulverized leaves $(1540 \mathrm{~g})$ and stems (1608 g) were extracted by static maceration at ambient temperature with hexane (Hex), ethyl acetate (EtOAc), and methanol $(\mathrm{MeOH})$ sequentially during three days with each solvent ${ }^{18}$. The procedure was repeated three times and concentrated on a rotary evaporator (Buchi R210; Switzerland, Flawil) at $50 \mathrm{mbar}$ and $35^{\circ} \mathrm{C}$, to yield a total of six extracts: leaf extracts, $71.00 \mathrm{~g}$ (Hex-L), $28.52 \mathrm{~g}$ (EtOAc-L), and $283.87 \mathrm{~g}$ (MeOH-L); and stem extracts, $39.44 \mathrm{~g}$ (Hex-S), $44.23 \mathrm{~g}$ (EtOAc-S), and $117.23 \mathrm{~g}$ (MeOH-S).

The most active extracts were partitioned. A portion of the dried methanolic leaf $(20 \mathrm{~g})$ and stem $(20 \mathrm{~g})$ extracts were then dissolved in methanol:water 9:1 v/v and sequentially partitioned three times with $400 \mathrm{~mL}$ of each solvent [(Hexano (Hex), dichloromethane (DCM), and ethyl acetate (EtOAc)] using a separatory funnel at room temperature (Figure 1). The solvents were removed using a rotary evaporator (Buchi R210; Switzerland, Flawil) at $35^{\circ} \mathrm{C}$ under vacuum. From the Hex leaves fraction (F-Hex-L), $0.59 \mathrm{~g}$ was obtained. The Hex stems fraction (F-Hex-S) yielded $0.19 \mathrm{~g}$, the DCM leaves fraction (F-DCM-L) $5.21 \mathrm{~g}$, the DCM stem fraction (F-DCM-S) $10.28 \mathrm{~g}$, the EtOAc leaves fraction (F-EtOAc-L) $1.82 \mathrm{~g}$, the EtOAc stems fraction (F-EtOAc-S) $2.02 \mathrm{~g}$, the aqueous leaves fraction (F-Aq-L) $11.15 \mathrm{~g}$, and the aqueous stems fraction (F-Aq-S) $6.37 \mathrm{~g}$.

\section{Phytochemical screening}

Using the most active extracts and their partitions phytochemical tests were done. Phytochemical screening to test for the presence of secondary metabolites (alkaloids, flavonoids, quinones, saponins, tannins, and terpenoids-steroids), carbohydrates, and fats in the extracts and fractions was carried out using standard procedures. Phytochemical screening results from tests on extracts and fractions revealed the presence or absence of the main secondary metabolites and other phytochemicals based on the presence $(+)$ or absence (-)

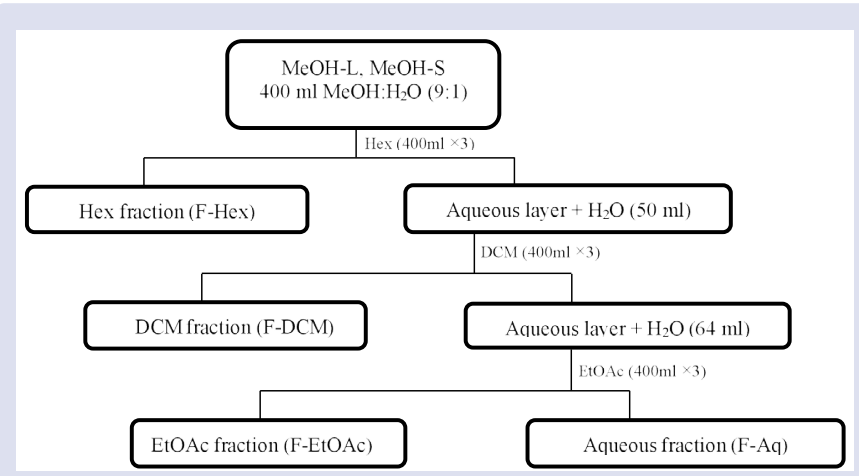

Figure 1: Fractionation scheme of the methanolic extracts from leaves and stems of Clusia latipes. of expected color changes. The tests performed were based on those reported in the literature ${ }^{19,20}$.

\section{Isolation of secondary metabolites}

The most active sample, the EtOAc leaves fraction (1.82 g), was separated by column chromatography with C18-reversed-phase silica gel (40-63 $\mu \mathrm{m}$; Merck) with extract:silica (g/g) proportion of $1: 20$, eluting with a gradient solvent system of $\mathrm{MeOH}-\mathrm{H}_{2} \mathrm{O}$ in $\mathrm{v} / \mathrm{v}$ ratios of 50:50, 60:40, $70: 30,80: 20,90: 10$, and 100:0 to obtain 200 eluates; according to the chromatographic profile in Thin-layer chromatography (TLC) analysis, 20 fractions were obtained (F1-F20).

Fractions with a good chromatographic profile were separated by column chromatography with silica gel $60(63-200 \mu \mathrm{m}$ : Merck) in proportion de 1:100 (extract:silica, g/g), eluting with mixtures of three solvents EtOAc- $\mathrm{MeOH}-\mathrm{H}_{2} \mathrm{O}$ in v/v ratios of 90:6:4, 85:10:5, 81:11:8, $77: 13: 10$, and 74:16:10. Finally, these are purified on a column of Sephadex LH-20 (Merck) with $\mathrm{MeOH}-\mathrm{H}_{2} \mathrm{O}$ 1:1 (v/v), obtaining a yellow amorphous solid, which was identified as isoquercitrin.

\section{Characterization and identification of secondary metabolites}

The melting point was determined using a Fisher Johns apparatus (Fisher Scientific Company, USA), and the temperature was not corrected. The ${ }^{1} \mathrm{H}(400 \mathrm{MHz})$ and ${ }^{13} \mathrm{C}$ NMR $(100 \mathrm{MHz})$ spectra were recorded on Varian $400 \mathrm{MHz}$-Premium Schelded equipment (Agilent Technologies, USA). $\mathrm{CD}_{3} \mathrm{OD}$ was used as the solvent, and chemical shifts were expressed in parts per million (ppm). Coupling constants $(J)$ were reported in $\mathrm{Hz}$.

\section{Assays for antioxidant capacity}

All extracts and fractions were evaluated for antioxidant capacity using stable free radicals of 2,2-diphenyl-1-picrylhydrazyl (DPPH) and 2,2-azinobis (3-ethylbenzothiazoline-6-sulfonic acid) diammonium salt (ABTS).

\section{DPPH radical scavenging assay}

DPPH free radical scavenging capacity was evaluated with a microplate analytical assay according to the literature ${ }^{21,22}$, with slight modifications. A $30-\mu \mathrm{l}$ aliquot of the different sample concentrations and standard were mixed with $270 \mu \mathrm{l}$ of $\mathrm{DPPH} \mathrm{H}^{\bullet}$ in methanol solution $100 \mu \mathrm{M}$ (O.D. adjusted to 1.1 at $515 \mathrm{~nm}$ ). After incubation at $20^{\circ} \mathrm{C}$ for $60 \mathrm{~min}$, the absorbance of each solution was measured using a microplate reader (EPOCH 2 BioTek; USA, Vermont) at $515 \mathrm{~nm}$. The percentage of scavenging activity was determined by following the equation described by Cheng et al. (2006):

$$
\left[1-\left(A_{\text {sample }}-A_{\text {blank }}\right) /\left(A_{\text {control }}-A_{\text {blank }}\right)\right] x 100 \text { (1) }
$$

The $\mathrm{SC}_{50}$ value was obtained through interpolation from linear or logarithmic regression analyses according to the behavior of the data, and the sample concentrations required to scavenge $50 \%$ of the DPPH radical were determined. Trolox was used as the reference compound.

\section{ABTS radical scavenging assay}

For the ABTS assay, the procedure followed the method of Thaipong et al. (2006) with slight modifications. From the different concentrations, a 30- $\mu \mathrm{l}$ aliquot was taken, and a $270 \mu \mathrm{l}$ of ABTS $^{\cdot+}$ solution (ABTS 7.4 $\mathrm{mM}$ and $2.6 \mathrm{mM}$ persulfate, $1: 1$ ratio) was added to a 96 -well microplate assay. This was incubated at $20^{\circ} \mathrm{C}$ for $60 \mathrm{~min}$, and the absorbance of each solution was recorded at $715 \mathrm{~nm}$ in a microplate reader $(\mathrm{EPOCH}$ 2 BioTek; USA, Vermont). The percentage of ABTS $^{*+}$ scavenging by the sample was calculated using the Eq. (1). Trolox was used as the reference compound. 


\section{a-glucosidase inhibitory activity}

Ten milligrams of each sample was dissolved in $1 \mathrm{ml}$ of methanol: $\mathrm{H}_{2} \mathrm{O}$ (1:1 ratio). In cases of complete inhibition, dilutions of the sample solution were made in phosphate-buffered saline (PBS; SIGMA).

The a-glucosidase enzyme inhibitory effect was determined using a 96well microtiter plate with $p$-nitrophenyl- $\alpha$-D-glucopyranoside ( $p$ NPG; SIGMA) as substrate according to the methods described by Tao et al. (2013), with slight modifications ${ }^{23}$. First, $5 \mu$ of the sample was mixed with $75 \mu \mathrm{l}$ of PBS (SIGMA) and $20 \mu \mathrm{l}$ of enzyme solution $(0.15 \mathrm{U} / \mathrm{ml}$ in PBS pH 7.4; SIGMA). This mixture was then pre-incubated at $37^{\circ} \mathrm{C}$ for $5 \mathrm{~min}$. After preincubation, $20 \mu \mathrm{l}$ of $p$ NPG $(5 \mathrm{mM}$ in phosphate buffer, $\mathrm{pH}$ 7.4) was added and then incubated at $37^{\circ} \mathrm{C}$. Acarbose $(5 \mathrm{mg} / \mathrm{ml})$ was used as a positive control. The amount of $p$-nitrophenol ( $p$-NP) released was measured at $405 \mathrm{~nm}$ for $60 \mathrm{~min}$, recording the absorbance every $5 \mathrm{~min}$ on a spectrophotometer microplate reader $(\mathrm{EPOCH} 2$ BioTek; USA, Vermont). The results were expressed as percentage inhibition using the formula previously described ${ }^{24}$ :

Inhibition $(\%)=[(A o-A s) / A o] \times 100(2)$

in which Ao is the absorbance recorded for the enzymatic activity without inhibitor (control) and $A$ s is the absorbance recorded for the enzymatic activity in the presence of the inhibitor (sample test). The $\mathrm{IC}_{50}$ was calculated using GraphPad Prism v 5.0 software.

\section{RESULTS}

Regarding antioxidant capacity, both in the DPPH free radical elimination activity test and ABTS free radical test, we found that the greater the polarity of the extracts, the greater the antioxidant capacity. Thus, leaf and stem methanol extracts had $\mathrm{SC}_{50}$ values of $6.44 \mu \mathrm{g} / \mathrm{ml}$ and $6.77 \mu \mathrm{g} / \mathrm{ml}$, respectively. In the ABTS free radical test, the methanolic extracts present $\mathrm{SC}_{50}$ values of $5.43 \mu \mathrm{g} / \mathrm{ml}$ for leaves and $4.59 \mu \mathrm{g} / \mathrm{ml}$ for stems (Table 1).

On the other hand, the a-glucosidase inhibitory activity was observed in vitro in all samples. The positive acarbose control had an $\mathrm{IC}_{50}$ of $377 \mu \mathrm{M}(243.39 \mu \mathrm{g} / \mathrm{ml})$, which was in good agreement with the results reported by Feng et al. (2011) ${ }^{25}$. Similar to the $\alpha$-glucosidase inhibitory activity, the samples that showed high activities were of methanolic extracts of leaves and stems with $\mathrm{IC}_{50}$ values of $5.01 \mu \mathrm{g} / \mathrm{ml}$ and $2.30 \mu \mathrm{g} /$ $\mathrm{ml}$, respectively (Table 1).

Given the activity of the extracts, the most effective extracts were fractionated according to the scheme presented in Figure 1. The results obtained from the phytochemical examination revealed the presence of alkaloids, carbohydrates, flavonoids/xanthones, quinones, saponins, and tannins (Table 2).

The antioxidant capacity and $\alpha$-glucosidase inhibitory activity were evaluated from the fractions of methanol extracts obtained from leaves and stem (Table 3). The antioxidant activities of the DCM, EtOAc, and aqueous leaf and stem fractions increased significantly relative to the Hex fractions. The fractions with the highest biological activity are those obtained in EtOAc (F-EtOAc), both in leaves and stems. The $\mathrm{SC}_{50}$ of F-EtOAc from leaves was $4.70 \mu \mathrm{g} / \mathrm{ml}$, and for DPPH and $3.29 \mu \mathrm{g} /$ $\mathrm{ml}$ for ABTS, thus exhibiting higher antioxidant activity for ABTS. The F-EtOAc stems had a DPPH antioxidant capacity of $\mathrm{SC}_{50}: 3.58 \mu \mathrm{g} / \mathrm{ml}$ and ABTS of $2.27 \mu \mathrm{g} / \mathrm{ml}$ (Table 3).

Similar to the extracts, the fractions with the highest antioxidant capacity also have the highest $\alpha$-glucosidase inhibitory activity. Thus, the F-EtOAc leaves and F-EtOAc stems exhibited potency, with $\mathrm{IC}_{50}$ values ranging from 0.90 to $3.88 \mu \mathrm{g} / \mathrm{ml}$ (Table 3 ).

Based on these results, the F-EtOAc leaf fraction was separated by column chromatography to obtain a flavonoid glycoside, isoquercitrin (7.3 mg); the structure is shown in Figure 2. The structural characterization of this compound was carried out by spectroscopic and spectrometric analyses and by comparison with published data $^{26,27}$.

Physical and spectroscopic characteristics of isoquercitrin: m.p: 239$242{ }^{\circ} \mathrm{C}$. ESI-MS $m / z 465[\mathrm{M}+\mathrm{H}]^{+}\left(\mathrm{C}_{21} \mathrm{H}_{20} \mathrm{O}_{12}\right) .{ }^{1} \mathrm{H}-\mathrm{NMR}(400 \mathrm{MHz}$; $\left.\mathrm{CD}_{3} \mathrm{OD}\right): \delta 3.21\left(1 \mathrm{H}, \mathrm{d}, J=3.2 \mathrm{~Hz}, \mathrm{H}-5^{\prime \prime}\right), 3.31\left(1 \mathrm{H}, \mathrm{s}, \mathrm{H}-4^{\prime \prime}\right), 3.42(1 \mathrm{H}$, m, H-3"), $3.48\left(1 \mathrm{H}, \mathrm{d}, J=2.3 \mathrm{~Hz}, \mathrm{H}-2^{\prime \prime}\right), 3.57(1 \mathrm{H}, \mathrm{d}, J=5.5 \mathrm{~Hz}, \mathrm{H}-6 \mathrm{~b})$, $3.70(1 \mathrm{H}, \mathrm{d}, J=1.9 \mathrm{~Hz}, \mathrm{H}-6 \mathrm{a}), 5.49\left(1 \mathrm{H}, \mathrm{s}, \mathrm{H}-1^{\prime \prime}\right), 6.19(1 \mathrm{H}, \mathrm{d}, J=2.0 \mathrm{~Hz}$,

Table 1: DPPH and ABTS free radical-scavenging activity and a-glucosidase inhibitory activity of Clusia latipes extracts.

\begin{tabular}{ccccc}
\hline \multirow{2}{*}{ Morphological structure } & \multirow{2}{*}{ Extracts } & $\mathrm{DPPH}$ & $\mathrm{ABTS}$ & \multicolumn{2}{c}{ a-glucosidase inhibitory } \\
& & $\mathrm{SC}_{50}(\mu \mathrm{g} / \mathrm{ml})$ & $\mathrm{SC}_{50}(\mu \mathrm{g} / \mathrm{ml})$ & $\mathrm{IC}_{50}(\mu \mathrm{g} / \mathrm{ml})$ \\
\hline \multirow{3}{*}{ LEAVES } & $\mathrm{Hex}$ & $>100$ & $64.80 \pm 0.21$ & $231.00 \pm 0.75$ \\
& $\mathrm{EtOAc}$ & $85.53 \pm 0.88$ & $42.45 \pm 0.52$ & $33.96 \pm 1.15$ \\
& $\mathrm{MeOH}$ & $6.44 \pm 0.52$ & $5.43 \pm 0.30$ & $5.01 \pm 0.75$ \\
\multirow{2}{*}{ STEMS } & $\mathrm{Hex}$ & $>100$ & $52.06 \pm 0.44$ & $177.40 \pm 0.48$ \\
& $\mathrm{EtOAc}$ & $46.93 \pm 0.69$ & $25.81 \pm 0.45$ & $5.80 \pm 0.02$ \\
& $\mathrm{MeOH}$ & $6.77 \pm 0.59$ & $4.59 \pm 0.34$ & $1.30 \pm 0.15$ \\
\hline
\end{tabular}

$\mathrm{Hex}=$ hexane; EtOAc = ethyl acetate; $\mathrm{MeOH}=$ methanol. All values were expressed as means \pm standard error $(\mathrm{n}=3)$.

Table 2: Phytochemical screening of methanolic extracts of $C$. latipes leaves and stems and their fractions.

\begin{tabular}{cccccccccccc}
\hline \multirow{2}{*}{ Compounds } & & \multicolumn{3}{c}{ LEAVES } & & \multicolumn{7}{c}{ STEMS } \\
& MeOH & F-Hex & F-DCM & F-EtOAC & F-Aq & MeOH & F-Hex & F-DCM & F-EtOAc & F-Aq \\
\hline Alkaloids & + & - & + & + & + & + & - & + & + & + \\
Carbohydrates & + & - & - & - & + & + & - & - & - & + \\
Fats & - & + & - & - & - & - & - & - & - & - \\
Flavonoids/ & + & - & + & + & + & + & - & + & + & + \\
Xanthones & + & & + & + & + & + & + & - & + & + & + \\
Quinones & + & - & + & + & + & + & - & - & + & + \\
Saponins & + & - & + & + & - & + & + \\
Tannins & + & - & - & - & + & + & - & - & + & + \\
Terpenoids- steroids & - & + & - & - & - & - & + & - & - & - \\
\hline
\end{tabular}

$+=$ presence, $-=$ absence 
Table 3: DPPH and ABTS free radical-scavenging activity and a-glucosidase inhibitory activity of fractions obtained from methanolic extracts of $C$. latipes leaves and stems.

\begin{tabular}{|c|c|c|c|c|}
\hline \multirow{2}{*}{ Morphological structure } & \multirow{2}{*}{$\begin{array}{c}\text { Fractions of methanol } \\
\text { extracts }\end{array}$} & DPPH & ABTS & a-glucosidase inhibitory \\
\hline & & $\mathrm{SC}_{50} \mu \mathrm{g} / \mathrm{ml}$ & $\mathrm{SC}_{50} \mu \mathrm{g} / \mathrm{ml}$ & $\mathrm{IC}_{50} \mu \mathrm{g} / \mathrm{ml}$ \\
\hline \multirow{3}{*}{ LEAVES } & F-Hex & $>100$ & $63.68 \pm 0.77$ & $102.80 \pm 0.43$ \\
\hline & F-DCM & $7.27 \pm 0.70$ & $5.74 \pm 0.38$ & $174.96 \pm 1.02$ \\
\hline & F-EtOAc & $4.70 \pm 0.80$ & $3.29 \pm 0.35$ & $0.90 \pm 0.12$ \\
\hline \multirow{5}{*}{ STEMS } & $\mathrm{F}-\mathrm{Aq}$ & $6.52 \pm 0.53$ & $5.03 \pm 0.68$ & $3.04 \pm 0.27$ \\
\hline & F-Hex & $>100$ & $70.16 \pm 0.57$ & $128.98 \pm 0.71$ \\
\hline & F-DCM & $6.86 \pm 0.48$ & $3.97 \pm 0.51$ & $110.85 \pm 0.10$ \\
\hline & F-EtOAc & $3.58 \pm 0.50$ & $2.27 \pm 0.51$ & $3.88 \pm 0.81$ \\
\hline & F-Aq & $4.20 \pm 0.43$ & $2.75 \pm 0.33$ & $2.98 \pm 0.13$ \\
\hline
\end{tabular}

All values were expressed as means \pm standard error $(n=3)$.

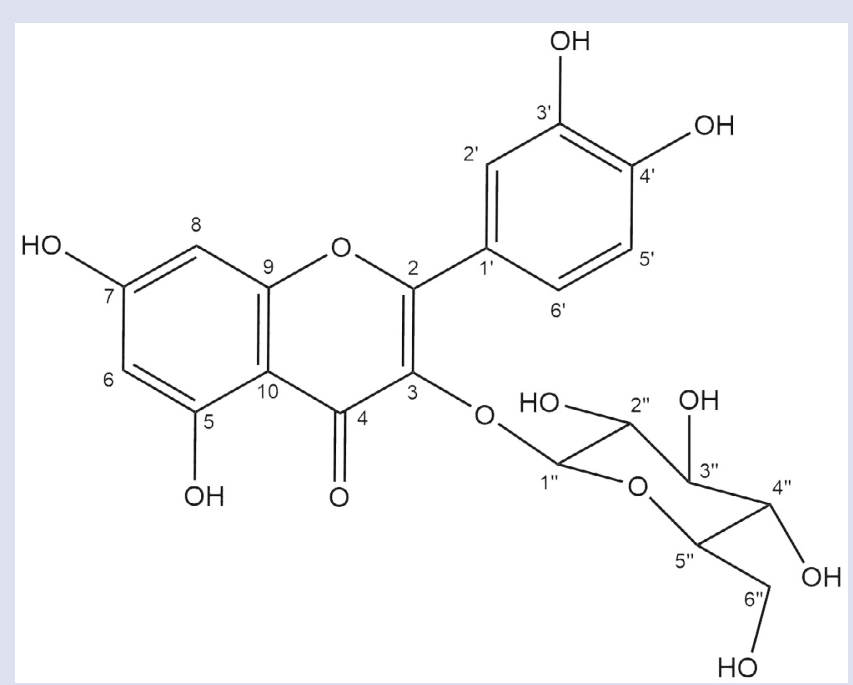

Figure 2: The chemical structure of isoquercitrin.
H-6), $6.38(1 \mathrm{H}, \mathrm{d}, J=1.9 \mathrm{~Hz}, \mathrm{H}-8), 6.88\left(1 \mathrm{H}, \mathrm{d}, J=1.0 \mathrm{~Hz}, \mathrm{H}-5^{\prime}\right), 7.62$ $\left(1 \mathrm{H}, \mathrm{dd}, J=2.2 \mathrm{~Hz}, \mathrm{H}-6^{\prime}\right), 7.64\left(1 \mathrm{H}, \mathrm{d}, J=1.1 \mathrm{~Hz}, \mathrm{H}-2^{\prime}\right) .{ }^{13} \mathrm{C}-\mathrm{NMR}(100$ $\mathrm{MHz} ; \mathrm{CD}_{3} \mathrm{OD}$ ): $\delta 61.0$ (s, C-6"), 70.0 (s, C-4"), 75.6 (s, C-2"), 76.8 (s, C-3"), 76.9 (s, C-5"), 93.2 (s, C-8), 99.4 (s, C-6), 103.9 (s, C-1"), 104.3 (s, C-10), 114.6 (s, C-2'), 115.9 (s, C-5'), 121.8 (s, C-6'), 121.9 (s, C-1'), 133.9 (s, C-3), 144.6 (s, C-4'), 148.3 (s, C-3'), 156.8 (s, C-2), 157.0 (s, C-9), 161.7 (s, C-5), 164.5 (s, C-7), 178.1 (s, C-4).

\section{DISCUSSION}

EtOAc fractions from methanolic extracts of leaves and stems had the most active DPPH antioxidant activity and were shown to be more effective than the Trolox positive control. The ranges of antioxidant capacity obtained are within similar ranges to other species of the same family, both for DPPH and ABTS ${ }^{28-31}$. Likewise, F-EtOAc leaf fractions had a-glucosidase inhibitory activity, similar to other species in the Clusiaceae family ${ }^{29,32-34}$. Flavonoids and xanthones have been isolated from some species of the Clusiaceae family ${ }^{34-38}$. There is a strong relationship between phenolic compounds from natural sources and $\alpha$-glucosidase inhibition ${ }^{39-43}$. Isoquercitrin is of interest to the food and pharmaceutical industries because of its biological properties as anti-inflammatory, hypotensive, anti-mutagenesis, anti-oxidative, anti-depressant, hypolipidemic, and anti-viral effects $^{27,44,45}$. It has been previously reported that isoquercitrin has several activities that are related to the control and prevention of diabetes ${ }^{46,47}$. Previously, it has been experimentally established that isoquercitrin has an $\alpha$-glucosidase inhibitory activity with an $\mathrm{IC}_{50}$ of $0.185 \mathrm{mM}^{48}$.

\section{CONCLUSION}

The highest $\alpha$-glucosidase inhibitory activity was detected in the ethyl acetate fraction obtained from leaf methanol extract, with a halfmaximal inhibitory concentration $\left(\mathrm{IC}_{50}\right.$ ) value of $0.90 \mu \mathrm{g} / \mathrm{ml}$. In this study, we observed an association between $\alpha$-glucosidase content and the antioxidant activities of the $C$. latipes fractions.

We propose that the $\alpha$-glucosidase inhibitory and antioxidant activities of $C$. latipes could be due to the presence of isoquercitrin.

\section{CONFLICTS OF INTEREST}

The authors declare no conflicts of interest.

\section{ACKNOWLEDGMENT}

The authors would like to thank James Salcedo-Ramírez for the contribution to the development of the tests for biological evaluation. This work has been financed by Universidad Técnica Particular de Loja (Grant PROY_CCSAL_1266).

\section{REFERENCES}

1. Gregg EW, Bracco P. The Dynamics of Diabetes Prevalence, Morbidity, and Mortality. In: In The Diabetes Textbook. Cham: Springer; 2019:11-21.

2. World Health Organization. Definition, Diagnosis and Classification of Diabetes Mellitus and Its Complications.; 1999.

3. World Health Organization. Global Report on Diabetes. 2016; 978:88.

4. Ullah A. Diabetes mellitus and oxidative stress -A concise review. Saudi Pharm J. 2016;24(5):547-53

5. Brownlee M. The pathobiology of diabetic complications a unifying mechanism 2005;54:1615-25.

6. Giacco F, Brownlee M. Oxidative stress and diabetic complications. Circ Res. 2014;107(9):1058-70.

7. Rahimi-Madiseh M, Malekpour-Tehrani A, Bahmani M, Rafieian-Kopaei M The research and development on the antioxidants in prevention of diabetic complications. Asian Pac J Trop Med. 2016;9(9):825-31.

8. Bolen S, Feldman L, Vassy J, Wilson L, Yeh H. Review Annals of Interna Medicine Systematic Review: Comparative Effectiveness and Safety of Oral Medications for Type 2 Diabetes Mellitus. Ann Intern Med. 2007;147:386-99.

9. Luthra T, Agarwal R, Estari M, Adepally U, Sen S. A novel library of -arylketones as potential inhibitors of $\alpha$-glucosidase : Their design, synthesis, in vitro and in vivo. Sci Rep. 2017;7:13246.

10. Saltos MBV, Puente BFN, Faraone I, Milella L, Tommasi N De, Braca A Inhibitors of $\alpha$-amylase and $\alpha$-glucosidase from Andromachia igniaria Humb. \& Bonpl. Phytochem Lett. 2015;14:45-50.

11. Cragg GM, Newman DJ. Natural products: a continuing source of novel drug leads. Biochim Biophys Acta. 2013;1830(6):3670-95.

12. Moura A, Perazzo F, Maistro E. The mutagenic potential of Clusia alata (Clusiaceae) extract based on two short-term in vivo assays. Genet Mol Res. 2008;7(4):1360-8.

13. Ferreira RO, Junior ARDC, da SilvaTMG, Castro RN, da Silva TMS, de Carvalho MG. Distribution of metabolites in galled and non-galled leaves of Clusia lanceolata and its antioxidant activity. Rev Bras Farmacogn. 2014;24(6):617-25. 
14. Camara CAG Da, Shepherd SLK, Joaquim DRG. Análise química da cultura de tecidos do híbrido Clusia paralicola X Clusia weddelliana. Rev Bras Farmacogn. 2002;12(Tabela 1):1-3.

15. Huerta-Reyes M, Basualdo MDC, Lozada L, Jimenez-Estrada M, Soler C, Reyes-Chilpa R. HIV-1 inhibition by extracts of Clusiaceae species from Mexico. Biol Pharm Bull. 2004;27(6):916-20.

16. Mangas Marín R, Montes de Oca Porto R, Bello Alarcón A, Nival Vázquez A. Caracterización por cromatografía de gases/espectrometría de masas del extracto apolar de las hojas de Clusia minor L. Lat Am J Pharm. 2008;27(5):74751.

17. Díaz-Carballo D, Gustmann S, Acikelli AH, et al. 7-epi-nemorosone from Clusia rosea induces apoptosis, androgen receptor down-regulation and dysregulation of PSA levels in LNCaP prostate carcinoma cells. Phytomedicine. 2012; 19(14):1298-1306.

18. Bailon-Moscoso N, Romero-Benavides JC, Sordo M, et al. Phytochemical study and evaluation of cytotoxic and genotoxic properties of extracts from Clusia latipes leaves. Brazilian J Pharmacogn. 2016;26(1):44-9

19. Mandal SC, Mandal V, Das AK. Qualitative Phytochemical Screening. Essentials Bot Extr. 2015:173-15.

20. Miranda M, Cuellar A. Farmacognosia y Productos Naturales. 2001;141.

21. Cheng Z, Moore J, Yu L. High-throughput relative DPPH radical scavenging capacity assay. J Agric Food Chem. 2006;54(20):7429-36.

22. Thaipong K, Boonprakob U, Crosby K, Cisneros-Zevallos L, Hawkins Byrne D. Comparison of ABTS, DPPH, FRAP, and ORAC assays for estimating antioxidant activity from guava fruit extracts. J Food Compos Anal. 2006;19(6-7):669-75.

23. Tao $Y$, Zhang $Y$, Cheng $Y$, Wang $Y$. Rapid screening and identification of $\alpha$-glucosidase inhibitors from mulberry leaves using enzyme-immobilized magnetic beads coupled with HPLC/MS and NMR. Biomed Chromatogr. 2013;27(2):148-55.

24. Matos MA, Tannuri $U$, Guarniero R. The effect of zoledronate during bone healing. J Orthop Traumatol. 2010;11(1):7-12.

25. Feng J, Yang XW, Wang RF. Bio-assay guided isolation and identification of $\alpha$-glucosidase inhibitors from the leaves of Aquilaria sinensis. Phytochemistry. $2011 ; 72(2): 242-7$.

26. Kazuma K, Noda N, Suzuki M. Malonylated flavonol glycosides from the petals of Clitoria ternatea. Phytochemistry. 2003;62(2):229-37.

27. Sukito A, Tachibana S. Isolation of hyperoside and isoquercitrin from Camellia sasanqua as antioxidant agents. Pakistan J Biol Sci. 2014;17(8):999-1006.

28. Kaennakam S, Mudsing K, Rassamee K, Siripong P, Tip-pyang S. Two new xanthones and cytotoxicity from the bark of Garcinia schomburgkiana. J Nat Med. 2018;73(1):257-61.

29. Sarma R, Kumari S, Elancheran R, Deori M, Devi R. Polyphenol rich extract of Garcinia pedunculata fruit attenuates the hyperlipidemia induced by high fat diet. Front Pharmacol. 2016;7(AUG):1-11

30. Ruma K, Sunil K, Prakash HS. Antioxidant, anti-inflammatory, antimicrobial and cytotoxic properties of fungal endophytes from Garcinia species. Int J Pharm Pharm Sci. 2013;5(SUPPL 3):889-97.

31. Sylvie DD, Anatole PC, Cabral BP, Veronique PB. Comparison of in vitro antioxidant properties of extracts from three plants used for medical purpose in Cameroon: Acalypha racemosa, Garcinia lucida and Hymenocardia lyrata. Asian Pac J Trop Biomed. 2014;4(Suppl 2):S625-32.

\section{GRAPHICAL ABSTRACT}

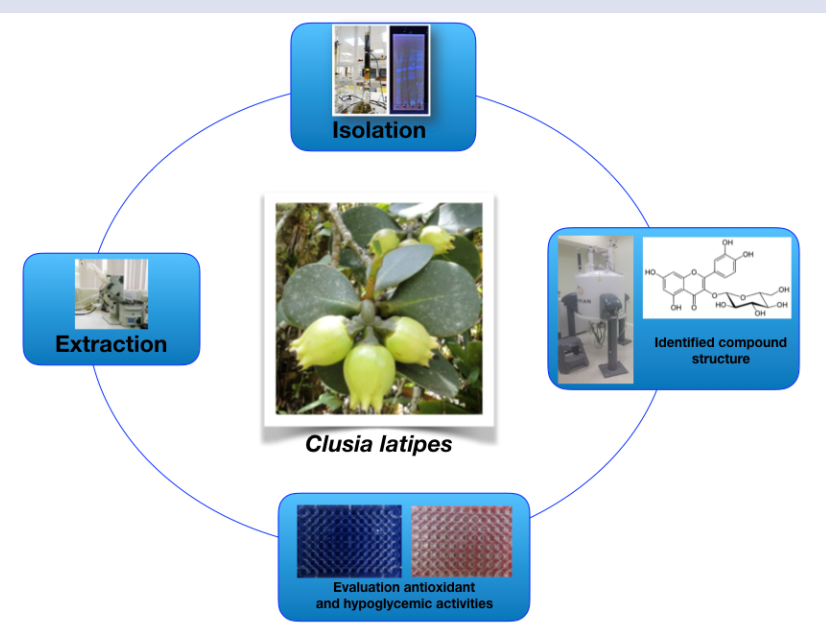

32. Ryu HW, Cho JK, Curtis-Long MJ, et al. $\alpha$-Glucosidase inhibition and antihyperglycemic activity of prenylated xanthones from Garcinia mangostana. Phytochemistry. 2011;72(17):2148-54.

33. Triadisti N, Rani Sauriasari BE. Fractionation and $\alpha$-glucosidase Inhibitory Activity of Fractions from Garcinia hombroniana Pierre Leaves Extracts. Pharmacogn J. 2017;9(4):488-92.

34. Karunanayake S, Sotheeswaran S, Uvais M, Sultanbawa S, Balasubramaniam S. Xanthones and triterpenes of Calophyllum tomentosum. Phytochemistry. 1981;20(6):1303-4.

35. Jamila N, Khan N, Khan AA, et al. In vivo Carbon Tetrachloride-Induced Hepatoprotective and in vitro Cytotoxic Activities of Garcinia hombroniana (Seashore Mangosteen). African J Tradit Complement Altern Med. 2017;14(2):374-82.

36. Elya B, He HP, Kosela S, Hanafi M, Hao XJ. A new cytotoxic xanthone from Garcinia rigida. Fitoterapia. 2008;79(3):182-4.

37. Gontijo VS, De Souza TC, Rosa IA, et al. Isolation and evaluation of the antioxidant activity of phenolic constituents of the Garcinia brasiliensis epicarp. Food Chem. 2012;132(3):1230-5.

38. Martha S, Elya B, Hanafi M. Comparison of inhibitory activity against the $\alpha$-glucosidase enzymes in the extracts and fractions from leaves of the Garcinia kydia Roxburgh. Asian J Pharm Clin Res. 2017;10(7).

39. Apostolidis E, Lee CM. In vitro potential of ascophyllum nodosum phenolic antioxidant-mediated $\alpha$-glucosidase and $\alpha$-amylase inhibition. J Food Sci. 2010;75(3).

40. Lordan S, Smyth TJ, Soler-Vila A, Stanton C, Paul Ross R. The $\alpha$-amylase and $\alpha$-glucosidase inhibitory effects of Irish seaweed extracts. Food Chem. 2013;141(3):2170-6.

41. Ferreres F, Gil-Izquierdo A, Vinholes J, Silva ST, Valentão P, Andrade PB. Bauhinia forficata Link authenticity using flavonoids profile: Relation with their biological properties. Food Chem. 2012;134(2):894-904.

42. Yilmazer-Musa M, Griffith AM, Michels AJ, Schneider E, Frei B. Grape Seed and Tea Extracts and Catechin 3-Gallates Are Potent Inhibitors of $\alpha$-Amylase and $\alpha$-Glucosidase Activity. J Agric Food Chem. 2012;60(36):8924-9.

43. Inthongkaew $P$, Chatsumpun N, Supasuteekul $C$, et al. $\alpha$-Glucosidase and pancreatic lipase inhibitory activities and glucose uptake stimulatory effect of phenolic compounds from Dendrobium formosum. Rev Bras Farmacogn. 2017;27(4):1-8

44. Valentová K, Vrba J, Bancírová M, et al. Isoquercitrin : Pharmacology, toxicology , and metabolism. Food Chem Toxicol. 2014;68:267-82.

45. Bailon-Moscoso N, Cevallos-Solorzano G, Romero-Benavides JC, Orellana Ramirez MI. Natural Compounds as Modulators of Cell Cycle Arrest: Application for Anticancer Chemotherapies. Curr Genomics. 2017;18(2):106-31.

46. Baba K. Antioxidant constituents in the dayflower (Commelina communis L.) and their a -glucosidase-inhibitory activity. 2008:349-53.

47. Zhang L, Zhang S, Yin Y, Xing S, LiW, Fu X. Hypoglycemic effect and mechanism of isoquercitrin as an inhibitor of dipeptidyl peptidase-4 in type 2 diabetic mice. R Soc Chem. 2018;8:14967-74.

48. LiYQZ, Gao FC, Bian F, Sheng JB, Shan F. Comparative Evaluation of Quercetin, Isoquercetin and Rutin as Inhibitors of r-Glucosidase. J Agric Food Chem. 2009;57:11463-8.

\section{SUMMARY}

All the data shown revealed the antioxidant and hypoglycemic capacity of the extracts of the leaves and stems of Clusia latipes. The highest $\alpha$-glucosidase inhibitory activity was detected in the ethyl acetate fraction; with a half-maximal inhibitory concentration $\left(\mathrm{IC}_{50}\right)$ value of $0.90 \mu \mathrm{g} / \mathrm{ml}$. Isoquercitrin was isolated from the fraction more active. 


\section{ABOUT AUTHORS}

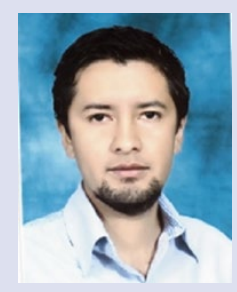

Ronald Silva-Rivas, He has a degree in Chemistry and Biology and also a master's degree in Chemistry Applied by the Universidad Tecncica Particulra de Loja.

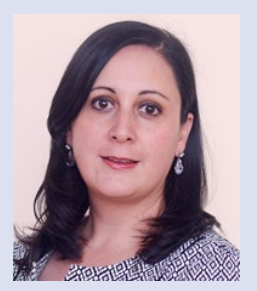

Natalia Bailon-Moscoso Ph.D. She is currently a Professor of Genetic, Medical Genetic and Molecular Pathology and Researcher in the Department of Health at Universidad Tecnica Particular de Loja, Ecuador, since October 2007. She is the Head of the Biomedicine and Environmental. Her interests are focused on the study of various chronic diseases (cancer, inflammation, metabolic syndrome) and how natural products could contribute to their treatment.

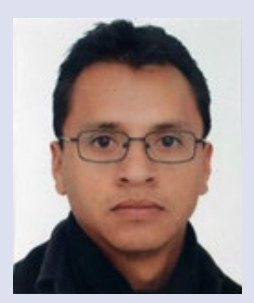

Dr. Luis Cartuche is currently the Head of the Bioassay laboratory, of the Chemistry Department at Universidad Tecnica Particular de Loja, Ecuador. He has over 10 years of experience in teaching Biochemistry. $\mathrm{He}$ is specialized in chemistry of natural products with a special interest in secondary metabolites isolated from marine actinobacteria and also, he conducts a battery of in vitro bioassays to determine antimicrobial and enzyme inhibition properties from natural matrices. He has published more than 16 scientific articles.

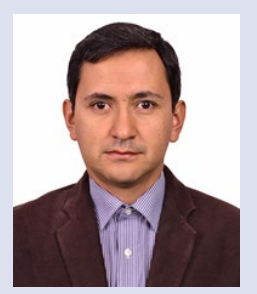

Juan Carlos Romero-Benavides Ph.D. He is currently Professor of Organic Chemistry and Chemistry of Natural Products and Researcher in the Department of Chemistry at Universidad Tecnica Particular de Loja, Ecuador, since October 2002. He is the Head of the Natural Products: cancer and parasitism research group (PNCyP). His main research interests focus on natural products (biochemistry and chemistry), synthetic methodology and natural product derivatization with the goal of discovering leads from natural sources and optimization of novel anti-inflammatory, anticancer and anti-parasitic drugs.

Cite this article: Silva-Rivas R, Bailon-Moscoso N, Cartuche L, Romero-Benavides JC. The Antioxidant and Hypoglycemic Properties and Phytochemical Profile of Clusia latipes Extracts. Pharmacog J. 2020;12(1):144-9. 